Transportation Research Forum

Stakeholder Contributions to Container Port Capacity: A Survey of Port Authorities Author(s): Michael J. Maloni and Eric C. Jackson

Source: Journal of the Transportation Research Forum, Vol. 46, No. 1 (Spring 2007), pp. 23-42

Published by: Transportation Research Forum

Stable URL: http://www.trforum.org/journal

The Transportation Research Forum, founded in 1958, is an independent, nonprofit organization of transportation professionals who conduct, use, and benefit from research. Its purpose is to provide an impartial meeting ground for carriers, shippers, government officials, consultants, university researchers, suppliers, and others seeking exchange of information and ideas related to both passenger and freight transportation. More information on the Transportation Research Forum can be found on the Web at www.trforum.org. 


\title{
Stakeholder Contributions to Container Port Capacity: A Survey of Port Authorities
}

\author{
by Michael J. Maloni and Eric C. Jackson
}

Given recent concerns about North American port congestion, this paper examines stakeholder involvement in expanding port capacity to meet significant volume growth. North American container port authorities were surveyed to identify key capacity factors and subsequent participation requirements by stakeholders such as terminal operators, longshore labor, railroads, steamship lines, truckers, and government. The resulting analysis indicates port frustration with participation currently offered by all stakeholders, especially the federal government and railroads. Such results further validate the requirement for a multi-stakeholder approach to port capacity expansion and suggest the need for national freight policy and planning leadership.

\section{INTRODUCTION}

More than $\$ 2.8$ trillion of goods flow into and out of U.S. ports annually, with almost $\$ 1$ trillion of that moving in over 42 million, 20-foot equivalent units (TEUs). (A 20-foot container represents one TEU and a 40-foot container represents two TEUs.) (National Chamber Foundation of the U.S. Chamber of Commerce 2003, American Association of Port Authorities 2006). Fueled by imports, North American container port volumes have consistently increased at a rate of $7 \%$ per year since 1990 with no foreseeable change to this growth. As shown in Figure 1, extrapolation of this growth

Figure 1: Container Volume History and Forecast: Continental United States and Canada

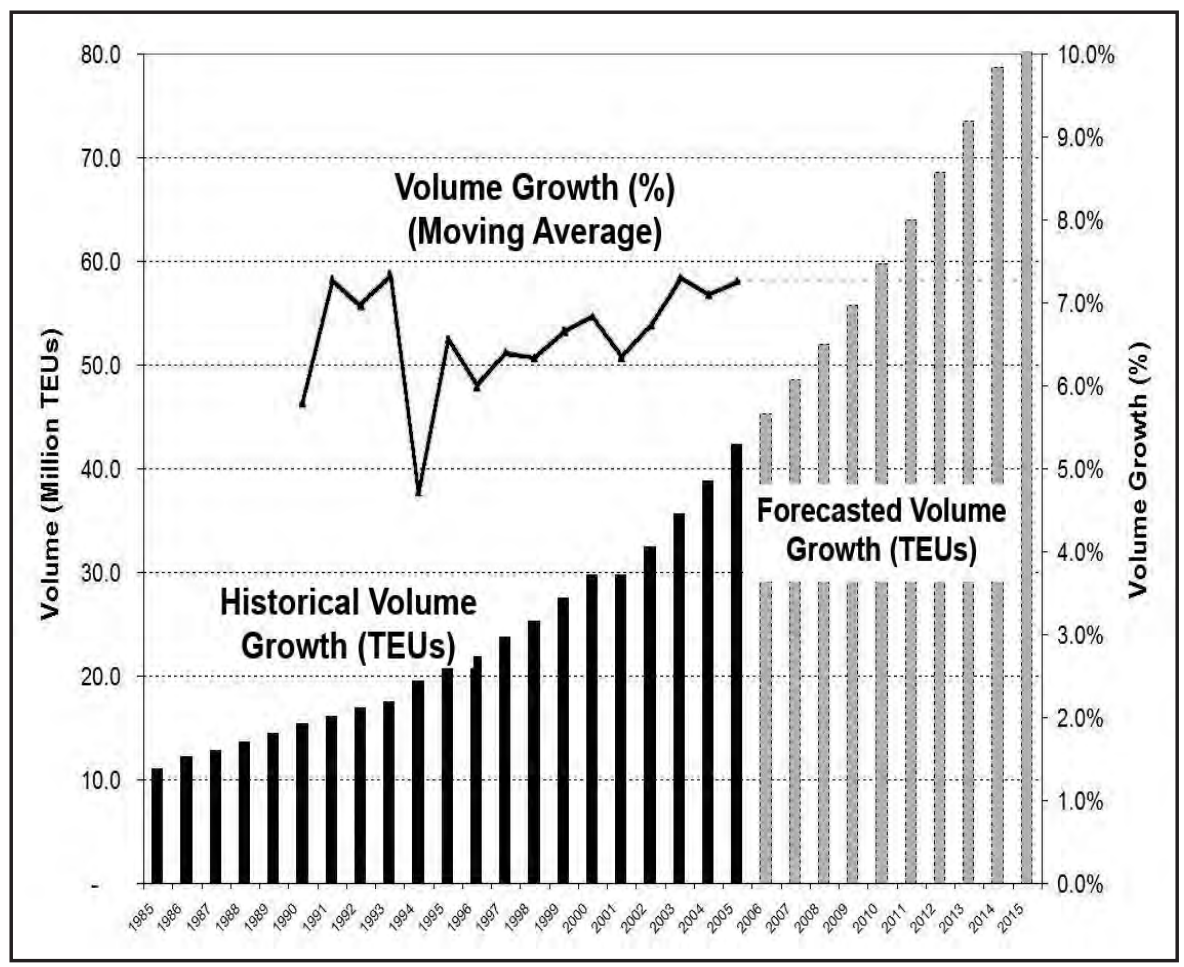

Source: American Association of Port Authorities (AAPA) 
rate projects that port volumes will double in approximately 10 years and will subsequently require significant port capacity expansion. For this paper, capacity is defined as the total annual TEU throughput at a port, including container unloading/loading, storage, and landside transport in and out of the port. Based on such a definition, it is possible for ports to expand capacity by increasing the productivity of current labor, equipment, and facilities (e.g. via technology) and also by adding labor, equipment, and facilities (e.g. expand terminal space).

Evidence is emerging that port capacity has not sufficiently increased to meet the continued volume growth. Peak season congestion has already become a common concern, especially on the West Coast. Additionally, there is not enough systemwide capacity to handle regional disturbances such as the 2002 West Coast lockout that caused more than 200 ships and 300,000 containers to be stranded (Gooley and Cooke 2002). Military deployments and weather disruptions have also produced regional short-term port capacity problems.

Several large-scale studies predict imminent port capacity problems. One report indicates that there will be a significant shortfall in capacity as soon as 2010 (National Chamber Foundation of the U.S. Chamber of Commerce 2003), while another predicts that capacity shortages will become chronic in eight years (Wilbur Smith Associates 2001). Moreover, several industry experts, including leaders from major transportation companies such as UPS, Maersk, APL, and Marine Terminals Corporation, have voiced significant concerns about the ability of North American ports to handle future volume growth (Armbruster 2004, Leach 2004, Mottley 2005).

\section{Port Stakeholders}

With long lead times and high budget requirements for port and container network capacity growth, action must be taken now to ensure continued import and export flows that are critical to the North American economy. However, port capacity growth is a complex issue involving many diverse stakeholders. Internally, the port authority, terminal operators, and longshore labor directly impact port capacity, but several external stakeholders, including steamship lines, railroads, truck carriers, shippers, freight forwarders, and federal, state and local governments, also influence capacity. These stakeholders have diverse and complex goals, which in turn often force action by other stakeholders. As an example, steamship lines are looking to the economies of scale of larger ship sizes, which in turn require ports to dredge channel depths and adapt berths and port equipment. To compound the problem, stakeholder objectives conflict at times. For instance, federal security mandates not only reduce container throughput velocities due to inspections but also cause ports to redirect funds away from capacity expansion projects.

Accommodating rapidly increasing container volumes is not only an issue of current port capacity and productivity but also a problem of container network (ports, railroads, truckers, roadways, etc.) capacity and productivity. Port capacity issues cannot be addressed by simply expanding the size or number of ports serving North America. The port situation must take into consideration all of the stakeholders reacting to one other as well as the environment in which they operate. Many industry practitioners are no doubt aware of the need to address port capacity from a multi-stakeholder approach. However, such opinions tend to be expressed anecdotally and little action has actually been taken. Furthermore, while academic research has offered an abundance of insight into the internal, usually localized operations of ports, such research does not tend to view the problem holistically across the multiple stakeholders nor does it address capacity problems from a systemwide, national view. Without systemwide, multi-stakeholder research, port capacity issues and subsequent resolution will be difficult to address, and capacity expansion efforts will remain only local and anecdotal. 


\section{RESEARCH OBJECTIVES}

The research presented in this paper assesses participation requirements of stakeholders for port capacity expansion. To do so, critical drivers of port capacity are first identified by reviewing current literature. Next, the effects of different stakeholders on these capacity drivers are evaluated in order to validate both the complexity of port capacity and the need for a multi-stakeholder approach to capacity expansion. Finally, survey data collected from North American port authorities is analyzed to assess both expected and actual levels of participation by the stakeholders to determine if all stakeholders are sufficiently supporting port capacity growth requirements.

\section{PORT CAPACITY DRIVERS AND STAKEHOLDER INFLUENCES}

Ports and their supporting container networks have received extensive yet fragmented attention as the popular press, government reports, and academic journals have all addressed issues associated with ports and their operations. In a recent literature review on the subject, Maloni and Jackson (2005a) identified over 200 papers associated with port capacity in the last 20 years. They organize the literature relative to stakeholder influences, revealing that port capacity is influenced by a wide array of internal and external port stakeholders. Their research shows that despite the wealth of research addressing port capacity influences, almost none of this research specifically addresses port capacity issues from the multiple stakeholder or national perspective that is necessary to address the urgency and complexity of adequate port capacity.

In follow-up work, Maloni and Jackson (2005b) present the results from a survey of port authorities. This research illustrates that the ports expect capacity and congestion issues to deteriorate in the next decade and that such problems may be compounded by under-forecasting of container volumes, especially at West Coast ports. The results also reveal the complexity of the port capacity issue by identifying more than 25 different capacity drivers, including many that are primarily under the control of external port stakeholders including railroads, truckers, and local and state government. Again, this highlights the need for a multi-stakeholder approach to port capacity.

To further consider port capacity from a multi-stakeholder view, the academic literature (primarily from business-focused transportation, logistics, and operations research journals) was first reviewed to evaluate past research that assesses port capacity in areas such as strategic planning, infrastructure, port operations, and rail/truck operations. Despite a wealth of academic literature in the area, such research tends to focus on specific aspects or stakeholders of port capacity rather than an aggregate, multi-stakeholder view. For instance, many works offer mathematical-based solutions for terminal operations (see Vis and de Koster 2003 for a review), berthing (Lim 1998, Nishimura et al. 2001), or equipment (Kim and Kim 1997, Kim and Park 2004). Other researchers have addressed the efficiency (Sanchez et al. 2003, Turner et al. 2004) and competitiveness (Murphy et al. 1992, Song and Yeo 2004) of ports, though there is still a need for such analyses to directly compare North American, European, and Asian ports.

Port labor has been examined from the standpoint of wages (Talley 2002, Talley 2004) and productivity (Silberholz et al. 1991). Technology adoption, which has been somewhat restrained at North American ports by labor unions, is addressed in works by Veras and Walton (1996), and Kia, Shayan, and Ghotb (2000). A series of works by Golob and Regan (2000, 2001, 2002, 2003) examine road congestion in and around ports. Additional examples of port capacity topics addressed by researchers include channel depth (Mohan and Palermo 1998), bridges (Mastaglio 1997), and land (Anonymous 1998).

Although the academic literature does not generally address port capacity from an aggregate, multi-stakeholder view, the research does provide solid input to capacity issues of North American ports. To better understand the specific, urgent factors influencing port capacity today, industry trade publication articles (primarily from daily newswires of American Shipper and Journal of Commerce) from 2004 through 2006 were next reviewed. Primary factors found include: 
- $\quad$ Security deals with protection at North American ports from terrorist acts and weapons of mass destruction. Security requirements such as container inspections can increase the time to move containers through the ports. Also, the monetary requirements of security programs can divert financial resources away from capacity projects.

- Environment concerns associated with ports include air emissions from ships, trucks, and locomotives as well as water pollution and effects on marine animals. Environment has become a particularly high-profile factor at West Coast ports.

- Funding for port capacity expansion can come from many sources, including port user fees, issuance of securities, and funding from governments at local, state, and national levels. However, port funding is generally tight, and other focuses such as security and environment can redirect funds away from capacity initiatives.

- Infrastructure refers to a port's land, berth space, terminal space for holding and moving containers, and equipment such as cranes and lifts. Productivity of the infrastructure at North American ports tends to be low relative to foreign ports, and physical expansion of infrastructure capacity is limited by a lack of space at many ports.

- Gate capacity deals with the speed at which containers can be trucked into and out of ports and includes both the number and efficiency of truck gates. Wait times at the gates slow container throughput and reduce capacity. As a secondary effect, long truck wait times also contribute to environmental issues in the form of emissions.

- Labor at most North American port terminals is contracted through labor unions. Labor productivity directly impacts port capacity. With a focus on protecting jobs, unions have sometimes blocked new technology that may increase labor productivity.

- Channel depth refers to the depth of the waterways for port access and berthing. Ocean carriers have utilized larger ships for economies of scale, requiring deeper port channels. Larger ship sizes also place greater strain on port equipment, rail, and truck capacity since greater numbers of containers arrive with each vessel call.

- Rail capacity into and out of ports is limited by the locomotive and equipment capacity of serving railroads, trackage in the port, and local trackage to connect to national rail lines. Many ports have increased the use of on-dock rail facilities to minimize truck drayage, but expanding rail capacity is extremely expensive.

- Truck capacity is a function of the number and efficiency of truck operators serving the ports as well as capacity of local roads. Equipment (e.g. chassis and tractors) shortages, driver shortages, and road congestion directly impact port throughput capacity.

- Technology in forms such as vessel and container scheduling, container tracking, and data exchange drives the efficient utilization of port facilities and subsequently port capacity. However, technology adoption at marine terminals has generally been slow.

Given this list of current port capacity factors, the academic and industry literature was next interpreted to logically relate each factor to the stakeholders who influence that factor. For example, many ports, especially those on the West Coast, face challenges to reduce the detrimental impact of port operations on the environment. Environmental standards in a region may be defined by federal, state, and local governments and influenced by public opinion from the local community. Pollution levels are affected by emissions from steamships, trucks, locomotives, and even port cranes and lifts. Thus, nearly all port stakeholders influence environmental requirements. Table 1 presents a matrix of stakeholder influences on port capacity factors and reveals that many factors are influenced by a wide array of stakeholders. This illustrates the complexity of stakeholder influences on port capacity and points to the need for a multi-stakeholder approach to addressing capacity factors.

\section{RESEARCH METHODOLOGY}

Given the need for a multi-stakeholder approach to address port capacity, stakeholder participation requirements were subsequently investigated to assess how much participation port authorities 


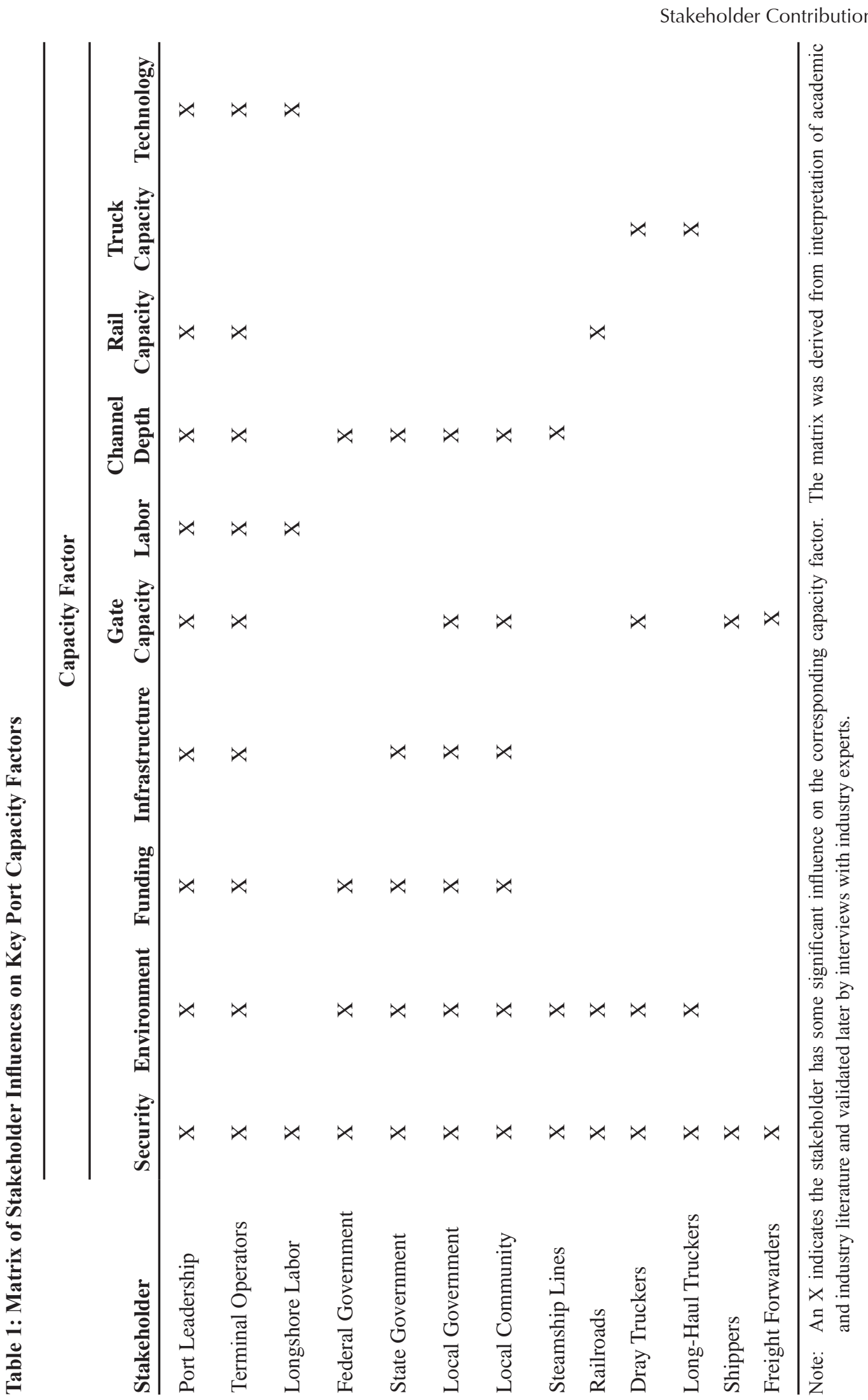

27 
Table 2: Continental United States and Canada Container Port Volumes (2005)

\begin{tabular}{|c|c|c|c|c|c|c|}
\hline Port & $\begin{array}{c}\text { State/ } \\
\text { Province }\end{array}$ & Country & Coast & $\begin{array}{c}2005 \\
\text { TEUs }\end{array}$ & $\begin{array}{c}\% \text { of Total } \\
\text { N. American } \\
\text { TEUs }\end{array}$ & $\begin{array}{c}\text { Cumm. \% } \\
\text { of Total N. } \\
\text { American } \\
\text { TEUs }\end{array}$ \\
\hline Los Angeles & $\mathrm{CA}$ & US & West & $7,484,624$ & $17.7 \%$ & $17.7 \%$ \\
\hline Long Beach & CA & US & West & $6,709,818$ & $15.9 \%$ & $33.6 \%$ \\
\hline $\begin{array}{l}\text { New York/ } \\
\text { New Jersey }\end{array}$ & NY, NJ & US & East & 4,792,922 & $11.3 \%$ & $44.9 \%$ \\
\hline Oakland & CA & US & West & $2,272,525$ & $5.4 \%$ & $50.3 \%$ \\
\hline Seattle & WA & US & West & $2,087,929$ & $4.9 \%$ & $55.2 \%$ \\
\hline Tacoma & WA & US & West & $2,066,447$ & $4.9 \%$ & $60.1 \%$ \\
\hline Charleston & SC & US & East & 1,986,586 & $4.7 \%$ & $64.8 \%$ \\
\hline Hampton Roads & VA & US & East & $1,981,955$ & $4.7 \%$ & $69.5 \%$ \\
\hline Savannah & GA & US & East & $1,901,520$ & $4.5 \%$ & $74.0 \%$ \\
\hline Vancouver & $\mathrm{BC}$ & CA & West & $1,767,379$ & $4.2 \%$ & $78.1 \%$ \\
\hline Houston & $\mathrm{TX}$ & US & Gulf & $1,582,081$ & $3.7 \%$ & $81.9 \%$ \\
\hline Montreal & QC & CA & East & $1,254,560$ & $3.0 \%$ & $84.9 \%$ \\
\hline Miami & FL & US & East & $1,054,462$ & $2.5 \%$ & $87.3 \%$ \\
\hline Port Everglades & FL & US & East & 797,279 & $1.9 \%$ & $89.2 \%$ \\
\hline Jacksonville & FL & US & East & 777,318 & $1.8 \%$ & $91.1 \%$ \\
\hline Baltimore & MD & US & East & 602,486 & $1.4 \%$ & $92.5 \%$ \\
\hline Halifax & NS & CA & East & 550,462 & $1.3 \%$ & $93.8 \%$ \\
\hline Fraser River & $\mathrm{BC}$ & CA & West & 372,844 & $0.9 \%$ & $94.7 \%$ \\
\hline Wilmington & $\mathrm{DE}$ & US & East & 250,507 & $0.6 \%$ & $95.3 \%$ \\
\hline Palm Beach & FL & US & East & 248,206 & $0.6 \%$ & $95.9 \%$ \\
\hline Philadelphia & $\mathrm{PA}$ & US & East & 204,912 & $0.5 \%$ & $96.3 \%$ \\
\hline New Orleans & LA & US & Gulf & 200,766 & $0.5 \%$ & $96.8 \%$ \\
\hline Gulfport & MS & US & Gulf & 187,384 & $0.4 \%$ & $97.3 \%$ \\
\hline Boston & MA & US & East & 186,578 & $0.4 \%$ & $97.7 \%$ \\
\hline Portland & OR & US & West & 160,479 & $0.4 \%$ & $98.1 \%$ \\
\hline Wilmington & NC & US & East & 148,784 & $0.4 \%$ & $98.4 \%$ \\
\hline St. John's & NF & CA & East & 110,995 & $0.3 \%$ & $98.7 \%$ \\
\hline San Diego & CA & US & West & 101,509 & $0.2 \%$ & $98.9 \%$ \\
\hline Freeport & TX & US & Gulf & 76,294 & $0.2 \%$ & $99.1 \%$ \\
\hline Toronto & ON & CA & East & 57,234 & $0.1 \%$ & $99.2 \%$ \\
\hline Saint John & NB & CA & East & 49,950 & $0.1 \%$ & $99.4 \%$ \\
\hline Mobile & $\mathrm{AL}$ & US & Gulf & 42,443 & $0.1 \%$ & $99.5 \%$ \\
\hline Richmond & VA & US & East & 41,963 & $0.1 \%$ & $99.6 \%$ \\
\hline All Contin & U.S. a & anada & & $42,296,007$ & & \\
\hline
\end{tabular}

Source: American Association of Port Authorities (AAPA). 
believe is required of all stakeholders to address capacity issues. To do so, a survey instrument was developed to capture capacity perceptions of North American container port authorities. Specific stakeholders and port capacity factors were identified for the survey based on the review of academic and practitioner literature discussed in the previous section. The most frequently discussed stakeholders and capacity factors were aggregated into a draft survey, which was then pilot-tested with industry and academic experts to confirm the accuracy, clarity, and completeness of the content. The final survey instrument (see Appendix A) had approximately 60 statements that were assessed with seven-point Likert response scales to allow for detection of smaller differences among opinions.

The largest container ports in North America were targeted for the survey. Ports not handling container shipping were excluded, as were Hawaii, Alaska and Puerto Rico ports that only handle local shipping demands. A total of 33 ports were identified as representing $99.6 \%$ of the cumulative North American containerized shipping and more than 42 million TEUs (Table 2). The survey was directed to port officials of the highest authority available, including titles such as "executive director," "CEO," "president," and "port director."

Of the 33 port officials surveyed, 24 replied for a response rate of $73 \%$. These participants represented $84 \%$ of the total containers shipped, thus constituting the majority of containerized goods flowing into and out of North America. Because of the small population size, non-response bias was assessed since it could significantly impact the survey results. Non-respondents were contacted to determine why they did not respond. While one of them indicated that they were decreasing their emphasis on commercial container shipping and as such elected not to respond, the rest of the non-respondents specified time constraints as their reason. Such feedback did not indicate any non-response bias. A comparison of responding and non-responding participants was also checked against capacity factors cited in the literature for both groups to see if any non-respondent port authorities appeared to have different capacity factors than respondents. In the authors' opinions, there appeared to be no differences. Given this, it was concluded that no non-response bias existed.

\section{RESEARCH ANALYSIS}

Survey responses were analyzed in several phases. First, the significance of port capacity factors was assessed, and the correlations among these factors were explored to demonstrate the complexity of port capacity problems as well as the requirement for a multi-stakeholder resolution. Next, the degree to which ports expect stakeholder participation to help address port capacity factors was evaluated. Finally, expected levels of participation were compared to actual levels to assess if all stakeholders are sufficiently contributing to capacity resolution efforts.

\section{Significance of Port Capacity Factors}

Port authorities were asked to assess the significance of factors affecting their capacity in the next five to 10 years on a scale of 1 (no significance) to 7 (high significance) (Appendix A). Multiple items were combined to form a single measure for some factors (e.g. port infrastructure included land, berth space, terminal space, and port equipment). Responses were combined across all ports and also by coast (East, Gulf, and West). The results were tested for statistical significance from a score of 1 (no significance) using a t-test with a finite population correction factor (Lind et al. 2005) due to the small population size (33 ports). Table 3 presents the results, showing that all 10 factors were found to have significant effects on port capacity aggregately across all ports and by individual coasts. This validates the complexity of port capacity expansion.

Two-population t-tests were then used to evaluate differences among the significance of port capacity factors by coast. Most differences were found to be statistically insignificant, and none were highly significant (i.e. p-value less than 0.01 ). However, four factors were found to show some evidence of statistical significance (p-value less than 0.10 but greater than 0.01 ). Table 4 
Table 3: Significance of Port Capacity Factors

\begin{tabular}{|c|c|c|c|c|c|c|c|c|c|c|c|c|}
\hline \multirow{2}{*}{$\begin{array}{c}\text { Capacity } \\
\text { Factor }\end{array}$} & \multicolumn{3}{|c|}{ All Ports } & \multicolumn{3}{|c|}{ East Coast Ports } & \multicolumn{3}{|c|}{ Gulf Coast Ports } & \multicolumn{3}{|c|}{ West Coast Ports } \\
\hline & ean & ie & ink & mean & $p$-value & rank & ean & $p$-value & rank & iean & $p$-value & rank \\
\hline & & & 6 & & & 2 & & & & & & 8 \\
\hline & 05 & 0 & 4 & 91 & 00 & 3 & .25 & & & .71 & & 5 \\
\hline & 5.77 & ח000 & 1 & 36 & 00 & 1 & 6.50 & & & 1.43 & 00 & 9 \\
\hline & 3.95 & & 7 & 3.84 & & 8 & 3.75 & & 9 & 4.26 & & 3 \\
\hline 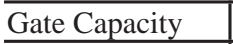 & 3.82 & & 9 & 45 & & & 4.25 & & 10 & 4.14 & 0 & 6 \\
\hline & 4.41 & & 8 & 91 & & 9 & 5.08 & & & 4.81 & 000 & 4 \\
\hline & 4.55 & $\underline{0}$ & 10 & 18 & 0 & & 5.00 & & & 3.29 & .001 & 10 \\
\hline & 4.61 & 00 & 3 & 4.32 & 0.000 & & 5.50 & & & 4.57 & 0.000 & 7 \\
\hline Truck Capacity & 4.80 & 0.000 & 2 & \begin{tabular}{|l|}
4.77 \\
\end{tabular} & 0.000 & 4 & 4.13 & 0.001 & 1 & 5.21 & 0.000 & 2 \\
\hline Technology & 3.87 & 0.000 & 5 & \begin{tabular}{|l|}
3.52 \\
\end{tabular} & 0.000 & 7 & 4.81 & 0.001 & 5 & 3.86 & 0.000 & 1 \\
\hline
\end{tabular}

Note: A p-value $<.01$ indicates a strong statistically significant difference from a value of 1 ("no significance" per survey wording), indicating the capacity factor has at least "moderate significance" in affecting port capacity in the next 5-10 years. Statistically significant values identified in bold.

presents these factors with the coast indicating a greater value on the left. For instance, East Coast ports viewed security as a more important factor than West Coast ports. This could be a result of the East Coast tending to receive more shipments from potential high-risk areas such as the Middle East and Eastern Europe. This could also result from the first five rounds of the Port Security Grants, which have favored some ports over others based on confidential considerations by the Department of Homeland Security. Next, both East Coast and Gulf Coast ports indicate stronger concern for funding than West Coast ports. Such a result could be influenced by the type and strength of the governing body of these port authorities. Finally, East Coast ports show a higher value for channel depth than West Coast ports, which is a reasonable finding given deeper natural channel depths at many West Coast ports.

Table 4: Differences in Significance of Port Capacity Factors Between Coasts

\begin{tabular}{cccc}
\hline $\begin{array}{c}\text { Coast } \\
\text { (Greater Value) }\end{array}$ & $\begin{array}{c}\text { Coast } \\
\text { (Lesser Value) }\end{array}$ & Capacity Factor & p-value \\
\hline East & West & Security & 0.027 \\
East & West & Funding & 0.052 \\
Gulf & West & Funding & 0.036 \\
East & West & Channel Depth & 0.031 \\
\hline
\end{tabular}

Note: Two-population t-tests were evaluated for differences in opinions between port groups by coast. A pvalue $<.10$ indicates some statistical evidence for a significant difference. All other combinations not listed were found to have no significant differences ( $\mathrm{p}$-values $>.10$ ).

\section{Correlation of Port Capacity Factors}

Next, a correlation analysis was conducted to assess both the influence of the above factors on future port capacity problems and the interrelatedness of these capacity factors. Future capacity shortages were measured by combining two questions that asked the port authorities to assess their agreement with statements indicating they expect capacity shortages in the next five- and 10 -year periods on a scale of 1 (strongly disagree) to 7 (strongly agree). Table 5 presents the resulting correlation matrix, including $\mathrm{p}$-values to indicate the statistical significance of the correlation coefficients ( $r$ ) from 0 (no correlation). 


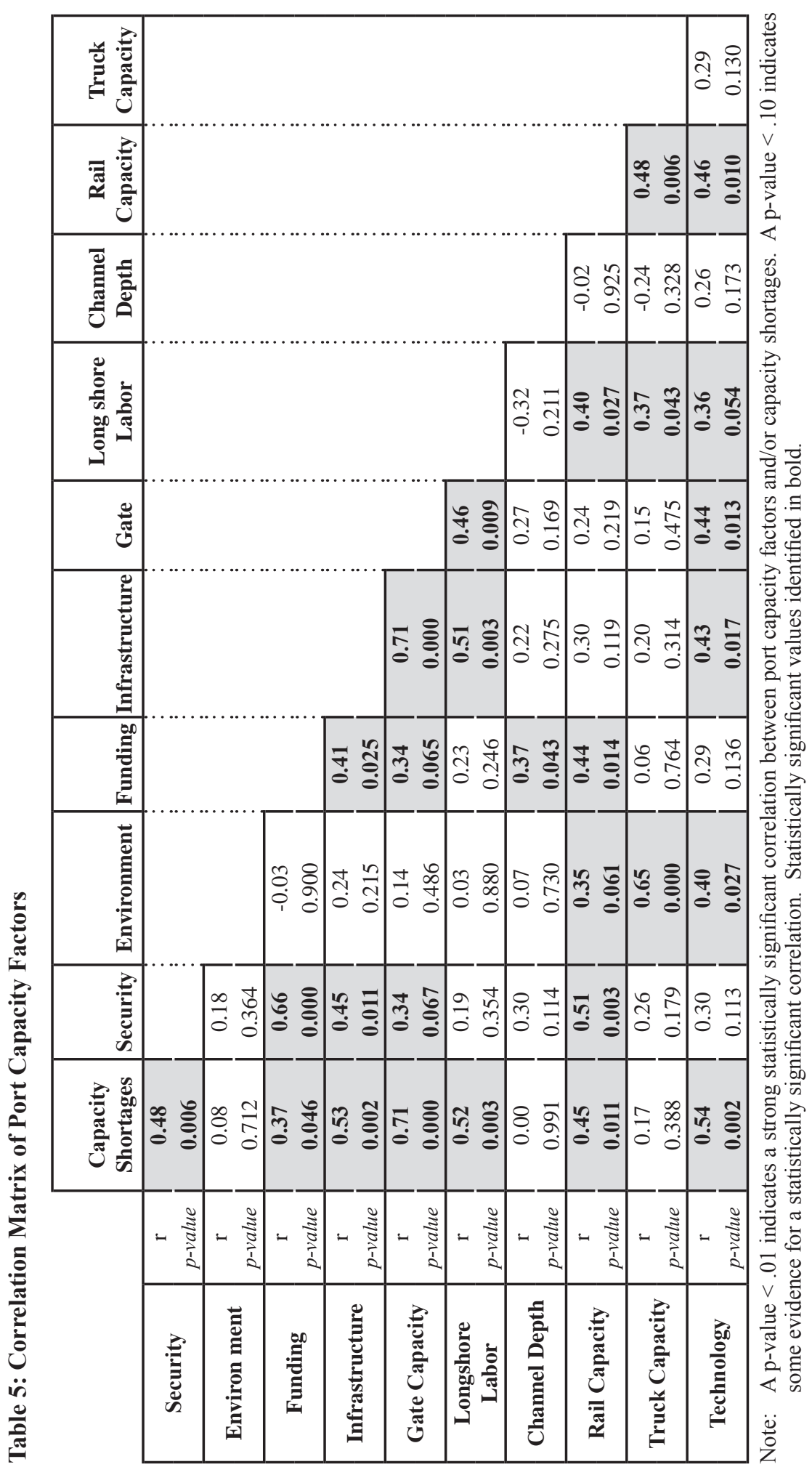


The correlation matrix reveals two compelling findings. As one, almost all capacity factors are strongly correlated with expected future capacity shortages, revealing the breadth and complexity of the problem. The most significant factors include gate capacity, technology, infrastructure, and longshore labor. The only exceptions are environment, channel depth, and truck capacity. This does not necessarily diminish the importance of these factors but rather indicates that there is not a consensus across all ports (across all regions) that these factors directly influence expected future capacity shortages. For instance, environment is currently a priority issue at many West Coast ports but not yet so at East and Gulf ports. As a second key finding, many capacity factors demonstrate significant correlations among one another, revealing an intricate inter-dependency among the factors. For instance, channel depth was not significantly correlated with potential capacity shortages but is strongly correlated with funding, which is highly correlated with congestion. So, capacity factors can have direct and indirect effects on overall port capacity.

Combining these two findings, it is clear that future port capacity shortages are influenced by many factors, which in turn, affect one another. Moreover, the previously discussed Table 1 , which related stakeholders to capacity factors, indicates that these factors are controlled by many different stakeholders. So resolving capacity shortages remains a multifaceted, complicated dilemma that will require a combined effort across a wide array of stakeholders. In other words, addressing only one or a few capacity factors and only a subset of port stakeholders will not effectively resolve future capacity problems. This validates current industry opinion that to this point has only been localized and anecdotal in nature.

\section{Expected Participation of Port Stakeholders}

Given the need for a combined effort across port stakeholders, the survey also asked the port authorities to assess levels of expected participation of the stakeholders in helping address port capacity factors on a scale of 1 (no expected participation) to 7 (high expected participation) (Appendix A). Responses were tested for a statistically significant difference from a score of 1 (no expected participation). The results are shown in Table 6 aggregately and by coast and validate that the ports expect at least some level of participation across all stakeholders. This once again verifies the need for a multi-stakeholder approach to addressing port capacity issues. Aggregately, the ports placed highest expected participation levels on their own leadership, terminal operators, steamship lines, longshore labor, and railroads.

Table 6: Expected Stakeholder Participation

\begin{tabular}{|c|c|c|c|c|c|c|c|c|c|c|c|c|}
\hline \multirow{2}{*}{ Stakeholder } & \multicolumn{3}{|c|}{ All Ports } & \multicolumn{3}{|c|}{ East Coast Ports } & \multicolumn{3}{|c|}{ Gulf Coast Ports } & \multicolumn{3}{|c|}{ West Coast Ports } \\
\hline & mean & $p$-value & rank & mean & $p$-value & rank & mean & p-value & rank & mean & $p$-value & rank \\
\hline Port Leadership & 6.36 & 0.000 & 1 & 6.36 & 0.000 & 1 & 6.00 & 0.000 & 1 & 6.57 & 0.000 & 2 \\
\hline Terminal Operators & 5.90 & 0.000 & 2 & 6.20 & 0.000 & 2 & 5.75 & 0.000 & 2 & 5.57 & 0.000 & 4 \\
\hline Steamship Lines & 5.41 & 0.000 & 3 & 5.36 & 0.000 & 3 & 5.25 & 0.001 & 6 & 5.57 & 0.000 & 8 \\
\hline Longshore Labor & 5.09 & 0.000 & 4 & 4.45 & 0.000 & 4 & 5.50 & 0.000 & 5 & 5.86 & 0.000 & 3 \\
\hline Railroads & 5.32 & 0.000 & 5 & 4.82 & 0.000 & 7 & 4.75 & 0.005 & 13 & 6.43 & 0.000 & 1 \\
\hline Federal Gov. & 5.14 & 0.000 & 6 & 4.73 & 0.000 & 5 & 5.25 & 0.002 & 10 & 5.83 & 0.000 & 5 \\
\hline Shippers & 4.82 & 0.000 & 7 & 4.27 & 0.000 & 10 & 5.00 & 0.001 & 7 & 5.57 & 0.000 & 6 \\
\hline Dray Truckers & 4.43 & 0.000 & 8 & 4.18 & 0.000 & 9 & 4.75 & 0.000 & 4 & 4.67 & 0.000 & 10 \\
\hline State Gov. & 5.00 & 0.000 & 9 & 5.00 & 0.000 & 6 & 4.75 & 0.002 & 9 & 5.20 & 0.002 & 12 \\
\hline Local Community & 4.62 & 0.000 & 10 & 4.64 & 0.000 & 8 & 4.25 & 0.002 & 11 & 4.83 & 0.000 & 11 \\
\hline Local Gov. & 4.59 & 0.000 & 11 & 4.00 & 0.000 & 13 & 4.50 & 0.003 & 12 & 5.57 & 0.000 & 6 \\
\hline Freight Forwarders & 3.91 & 0.000 & 12 & 3.73 & 0.000 & 12 & 4.50 & 0.001 & 8 & 3.86 & 0.000 & 9 \\
\hline Long-Haul Truckers & 3.76 & 0.000 & 13 & 3.82 & 0.000 & 11 & 5.00 & 0.000 & 3 & 2.83 & 0.004 & 13 \\
\hline
\end{tabular}

Note: A p-value $<.01$ indicates a strong statistically significant difference from a value of 1 ("no expected participation" per survey wording), indicating at least a "medium” level of expected stakeholder participation. Statistically significant values identified in bold. 
To test for any significant differences in levels of expected participation across port regions, two-population t-tests were evaluated by coast. Only four moderately significant differences were found (Table 7). First, West Coast ports indicated more expected participation of both railroads and longshore labor than East Coast ports. The difference in railroad participation may arise from the higher container volumes on the West Coast and thus potential greater impact of rail, especially considering the high volume of Asia-origin land bridge moves to other regions. The difference in longshore labor may result from the relative power of the ILWU on the West Coast with possible spillover effects from the labor dispute in 2002. Next, Gulf ports indicate higher participation levels of long-haul truckers than both East and West Coast ports, indicating that Gulf ports place higher emphasis on truck moves for future expansion.

Table 7: Differences in Expected Participation Between Coasts

\begin{tabular}{cccc}
\hline $\begin{array}{c}\text { Coast } \\
\text { (Greater Value) }\end{array}$ & $\begin{array}{c}\text { Coast } \\
\text { (Lesser Value) }\end{array}$ & $\begin{array}{c}\text { Capacity } \\
\text { Factor }\end{array}$ & p-value \\
\hline West & East & Railroads & 0.018 \\
West & East & Longshore Labor & 0.055 \\
Gulf & East & Long-Haul Truck & 0.078 \\
Gulf & West & Long-Haul Truck & 0.030 \\
\hline
\end{tabular}

Note: Two-population t-tests were evaluated for differences in opinions between port groups by coast. A pvalue $<.10$ indicates some statistical evidence for a significant difference. All other combinations not listed were found to have no significant differences ( $p$-values $>.10$ ).

\section{Sufficiency of Port Stakeholders Participation}

The port authorities were also asked to rate actual participation (as opposed to "expected" participation assessed above) of the stakeholders in supporting port efforts to address capacity factors, rating each stakeholder on a scale of 1 (no actual participation) to 7 (high actual participation). Subtracting actual participation from expected participation, an assessment of the sufficiency of stakeholder participation is derived (essentially representing paired t-tests of expected versus actual participation). In other words, if a stakeholder's actual participation meets expected levels, the difference would be 0 . However, if the stakeholder's actual participation is not sufficiently meeting expected participation levels, the difference would be a positive number (i.e. statistically significantly greater than 0 ).

The resulting measures of participation sufficiency were assessed for statistical significance from a difference of 0 (i.e. expected and actual participation are the same), once again using a finite population correction factor. Table 8 presents the results across all ports and by coast. Surprisingly, all stakeholders, including the port leadership itself, were found to have a significant difference, meaning that all stakeholders are perceived by the ports to not be devoting sufficient actual participation levels to addressing port capacity. The most problematic stakeholders appear to be the federal government and railroads. Shippers, steamship lines, and state government are also rank highly. Thus, the ports are clearly indicating frustration with insufficient stakeholder participation, even looking inward at their own port authority leadership.

Two-population t-tests were again used to evaluate significant differences in participation insufficiency across coasts (Table 9). Like previous tests, no results were highly statistically significant though several demonstrated moderate evidence of statistical significance. For example, West Coast ports indicated greater insufficiency of participation for steamship lines than Gulf Ports. Like the 2004 peak season congestion at Los Angeles and Long Beach, this is another indication of the need for stronger working relationships between the ports, terminal operators, and the steamship 


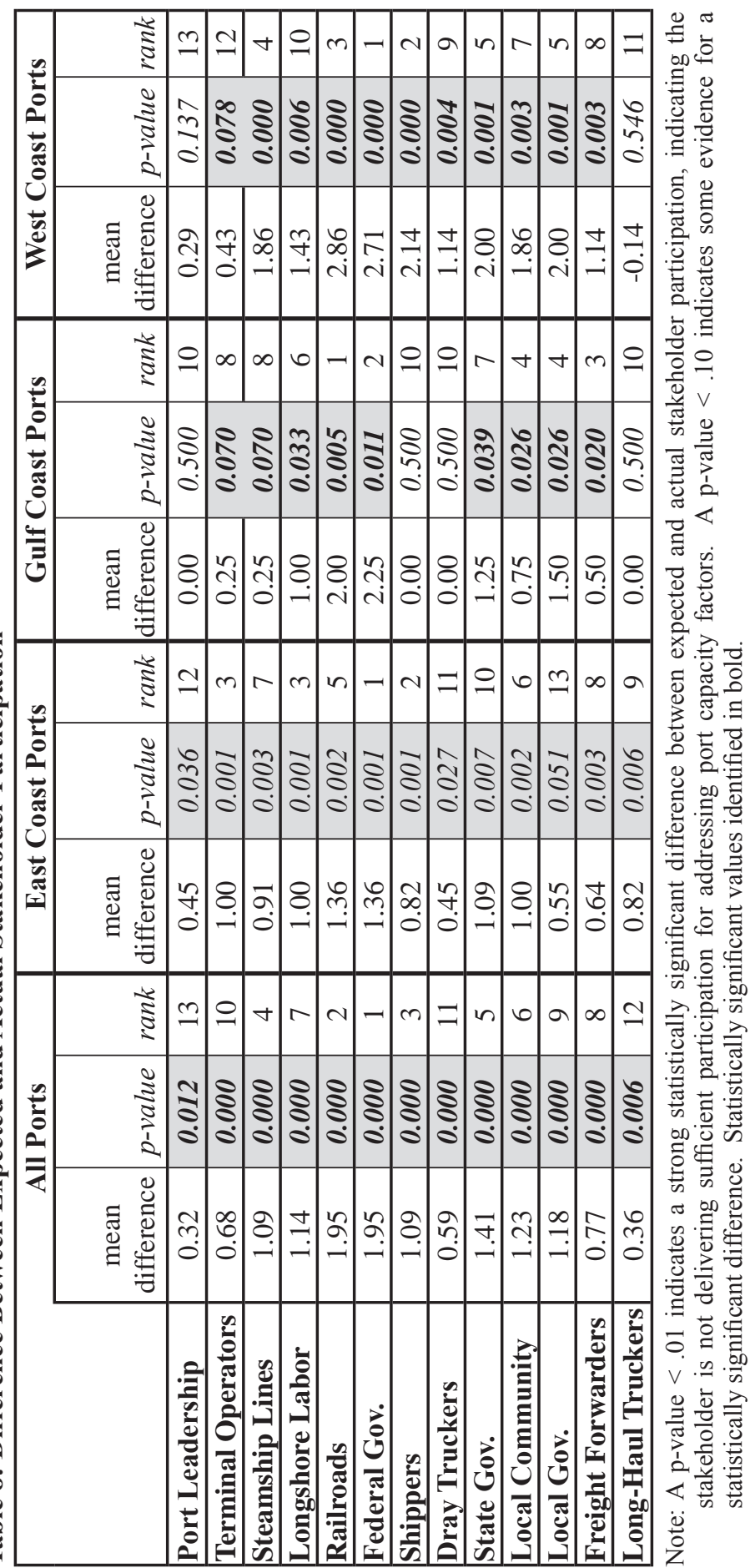


lines to better coordinate vessel calls. Additionally, all three regions differed in their opinions of the insufficiency of shipper participation. This highlights port desire for greater coordination with shippers, perhaps as a way to smooth out peak season demand experienced most heavily on the West Coast. Finally, East Coast ports indicate greater insufficiency of participation with long-haul truckers since Gulf and West Coast ports do not appear to be individually concerned with long-haul trucker participation.

Table 9: Differences in Participation Insufficiency Between Coasts

\begin{tabular}{cccc}
\hline $\begin{array}{c}\text { Coast } \\
\text { (Greater Value) }\end{array}$ & $\begin{array}{c}\text { Coast } \\
\text { (Lesser Value) }\end{array}$ & $\begin{array}{c}\text { Capacity } \\
\text { Factor }\end{array}$ & p-value \\
\hline West & Gulf & Steamship Lines & 0.038 \\
East & Gulf & Shippers & 0.020 \\
West & East & Shippers & 0.077 \\
West & Gulf & Shippers & 0.011 \\
East & Gulf & Long Haul Truck & 0.068 \\
East & West & Long Haul Truck & 0.043 \\
\hline
\end{tabular}

Note: Two-population t-tests were evaluated for differences in opinions between port groups by coast. A $\mathrm{p}$-value $<.10$ indicates some statistical evidence for a significant difference. All other combinations not listed were found to have no significant differences (p-values $>.10)$.

\section{DISCUSSION}

The United States Department of Transportation (2006) estimates that congestion costs the U.S. economy as much as $\$ 200$ billion annually due to delays, and the port system is not immune to this problem. Rapidly rising container volumes have strained port capacity, and port congestion is expected to continue to worsen. The research presented here reveals that port capacity is a complex problem with influences from many disparate stakeholders. So, the problem of port congestion is actually one of nationwide container network capacity, and multiple stakeholders must cooperate to address the growing problem. Port authorities must expand space and equipment, terminal operators and longshore labor must improve efficiency, and railroads and truck carriers must grow capacity. Likewise, governments at local, state, and federal levels must support such growth with creative funding opportunities to other stakeholders. All of this has to be accomplished in the presence of increasing security and environmental requirements that will divert funding and attention away from capacity expansion efforts.

Stronger leadership is needed to coordinate the array of stakeholders to address port and container network capacity, yet none of the stakeholders beyond the federal government retains the power and budget to lead the entire effort. So far, there has been no aggregate coordination of stakeholders in a national effort, and even the DOT has only initially indicated recognition of congestion issues.

A more definitive and impactful federal freight infrastructure policy is needed, and governments at both the federal and regional levels must lead public-private coordination for capacity expansion. The results presented in this paper should serve as a call-to-action for government resources to take stronger responsibility for recognizing the urgency of additional port and container network capacity.

There have been some success stories of capacity expansion, primarily in the form of PublicPrivate Partnerships (PPP) to address rail capacity. With equipment and labor capacity issues, railroads are often reluctant to invest capital in trackage, especially when other parties (e.g. ports) will also benefit without investment. So, PPPs help encourage track expansion. The $\$ 2.4$ billion, 
multi-decade Alameda Corridor project in California represents one example. The Corridor rail line from the ports of Long Beach and Los Angeles was developed jointly by port authorities, railroads, and local government. It has made significant increases to rail capacity in the area and subsequently reduced congestion and pollution. Despite these advances, the region still faces significant capacity problems with the ports, local roads, and even connections with national rail lines. Other current PPP rail projects include the Heartland Corridor from the Port of Virginia to the Midwest and the Chicago Regional Environmental and Transportation Efficiency (CREATE) project.

Major port expansion efforts have primarily been localized with some instances of publicprivate coordination. As an example, the new APM Terminals facility in Virginia did include some coordination with government organizations (such as the Virginia Department of Transportation), local longshore labor (ILA), railroads (primarily the Genesee \& Wyoming), and even shippers to a certain extent. The Prince Rupert Container Terminal in British Columbia represents a more significant multi-stakeholder capacity project. This terminal is being developed by the Prince Rupert Port Authority (PRPA), Maher Terminals, and the Canadian National (CN) Railway. The location was chosen due to a naturally deep harbor, room for expansion, and limited population congestion, presenting significant advantages over many existing North American ports. Equipment, including super post-Panamax cranes, will be able to handle larger ship sizes. In general, only a few largescale port expansion projects are under way in North America, however. Greater port expansion efforts appear to be taking place in Mexico, which is looking to capitalize on tight North American port capacity by initiating high volume service into the U.S. and Canada through new potential facilities at Punta Colonet, Lazaro Cardenas, and Guaymas.

While projects like the Alameda Corridor and Prince Rupert represent positive examples to address capacity, these projects remain regional and will not make a significant long-term impact on total North American container capacity. Such projects also demonstrate that large amounts of time and capital are required to generate improvements on just one portion of the North American container network. While there has not been a repeat of the congestion of 2004, the industry has appeared to take the unrealistic hope each year that peak season volumes will not result in any port congestion and thus justify delaying action for addressing capacity problems. As such, capacity problems may be beyond repair by the time port congestion becomes a routine problem due to the long lead time needed to expand port and supporting network capacity. Given the economic impact of North American imports and exports, significant action must be initiated immediately to ensure port and container network capacity issues do not prove detrimental to North American and global economies.

Beyond expanding port infrastructure, North American port efficiency offers a significant opportunity for capacity growth. It is estimated the North American ports are half as efficient as foreign ports due to technology and labor issues (Mongelluzzo 2006). As an efficiency improvement example, PierPass, the expanded gate hours program at Los Angeles and Long Beach, has successfully alleviated some terminal trucking congestion, though at the expense of additional fees to shippers. There have also been promising implementations of software and radio frequency identification (RFID) to sequence container moves and optimize use of port and drayage equipment.

\section{CONCLUSIONS}

The research presented here sought to highlight the importance of a multi-stakeholder approach to address future port capacity given increasing container volumes. Critical factors of port capacity were first identified via a review of industry and academic literature. These factors were then related to the many stakeholders that influence such factors. Next, survey data from North American port authorities was collected to assess their opinions of capacity problems, capacity factors, and required stakeholder participation. A correlation analysis revealed that future port capacity is significantly correlated with the different factors and that many of these factors are correlated among one another. This validated the complexity and breadth of port capacity improvements, signifying that most or 
all of these factors must be simultaneously addressed via subsequent participation by the impacting stakeholders to ultimately improve port capacity to meet future container volumes. Finally, port authorities' opinions of expected and actual levels of participation of each stakeholder to addressing port capacity needs were assessed. The results indicate that the port authorities view all stakeholders as not contributing sufficient actual participation, signifying a frustration with stakeholder efforts to address port capacity needs.

This research has highlighted the need for a comprehensive solution to container port congestion across a wide array of stakeholders. As previously mentioned, Maloni and Jackson (2005a) show that the existing literature usually only examines influences by one or a few stakeholders. The urgency of rising container volumes and port capacity issues thus necessitates that future research must consider the interrelated capacity influences of all stakeholders before an effective, systematic solution to port congestion may be considered. This should lead to a single unified effort to address container port capacity issues from both internal and external perspectives.

\section{References}

American Association of Port Authorities. www.aapa-ports.org, Retrieved July 1, 2006.

Anonymous. "Ports Desperate for Space and Dredging Options." Civil Engineering 68 (5), (1998): 10-11.

Armbruster, W. "U.S. Infrastructure Biggest Challenge to China Trade.” Journal of Commerce Online Edition, Retrieved Oct. 7, 2004.

Golob, T. F. and A. C. Regan. "Freight Industry Attitudes Towards Policies to Reduce Congestion.” Transportation Research. Part E, Logistics \& Transportation Review 36E (1), (2000): 55-77.

Golob, T. F. and A. C. Regan. "Impacts of Highway Congestion on Freight Operations: Perceptions of Trucking Industry Managers.” Transportation Research Part A: Policy and Practice 35 (7), (2001): 577-599.

Golob, T. F. and A. C. Regan. "The Perceived Usefulness of Different Sources of Traffic Information to Trucking Operations." Transportation Research. Part E, Logistics \& Transportation Review 38E (2), (2002): 97-116.

Golob, T. F. and A. C. Regan. "Traffic Congestion and Trucking Managers' Use of Automated Routing and Scheduling." Transportation Research. Part E, Logistics \& Transportation Review 39E (1), (2003): 61-78.

Gooley, T. and J. A. Cooke. “Shippers, Carriers Struggle with Port Shutdown's Aftermath.” Logistics Management 41 (11), (2002): 15-16.

Kia, M., E. Shayan and F. Ghotb. “The Importance of Information Technology in Port Terminal Operations." International Journal of Physical Distribution \& Logistics Management 30 (3/4), (2000): 331-344.

Kim, K. H. and Y. M. Park. “A Crane Scheduling Method for Port Container Terminals.” European Journal of Operational Research 156 (3), (2004): 752-768.

Kim, K. Y. and K. H. Kim. "A Routing Algorithm for a Single Transfer Crane to Load Export Containers onto a Containership.” Computers \& Industrial Engineering 33 (3,4), (1997): 673-676. 
Leach, P. T. “Global Congestion to Slow Trade: APL Chief.” Journal of Commerce Online Edition, Retrieved Nov. 17, 2004.

Lim, A. “The Berth Planning Problem.” Operations Research Letters 22 (2-3), (1998): 105-110.

Lind, D. A., W. G. Marchal and S. A. Wathen. Statistical Techniques in Business and Economics. McGraw-Hill, Boston, 2005.

Maloni, M. and E. C. Jackson. "North American Container Port Capacity: A Literature Review." Transportation Journal 44 (2), (2005a): 16-36.

Maloni, M. and E. C. Jackson. "North American Container Port Capacity: An Exploratory Analysis." Transportation Journal 44 (3), (2005b): 1-22.

Mastaglio, L. “Bridge Bashing.” Civil Engineering 67 (4), (1997): 38-40.

Mohan, R. K. and M. R. Palermo. “Bottoms Up.” Civil Engineering 68 (12), (1998): 56-59.

Mongelluzzo, B. "Labor, Management Co-Op Key to Productivity Gains." Journal of Commerce Online Edition, Retrieved March 8, 2006.

Mottley, R. “Bruner Speaks His Mind.” American Shipper 47 (1), (2005): 70-76.

Murphy, P. R., J. M. Daley and D. R. Dalenberg. "Port Selection Criteria: An Application of a Transportation Research Framework.” Logistics and Transportation Review 28 (3), (1992): 237255.

National Chamber Foundation of the U.S. Chamber of Commerce. Trade and Transportation, a Study of North American Port and Intermodal Systems, 2003.

Nishimura, E., A. Imai and S. Papadimitriou. "Berth Allocation Planning in the Public Berth System by Genetic Algorithms.” European Journal of Operational Research 131 (2), (2001): 282-292.

Sanchez, R. J., J. Hoffmann, A. Micco, G. V. Pizzolitto, M. Sgut and G. Wilmsmeier. "Port Efficiency and International Trade: Port Efficiency as a Determinant of Maritime Transport Costs." Maritime Economics \& Logistics 5 (2), (2003): 199-218.

Silberholz, M. B., B. L. Golden and E. K. Baker. "Using Simulation to Study the Impact of Work Rules on Productivity at Marine Container Terminals." Computers \& Operations Research 18 (5), (1991): 433-452.

Song, D. W. and K. T. Yeo. "A Competitive Analysis of Chinese Container Ports Using the Analytic Hierarchy Process.” Maritime Economics \& Logistics 6 (1), (2004): 34-52.

Talley, W. K. "Dockworker Earnings, Containerisation, and Shipping Deregulation.” Journal of Transport Economics and Policy 36 (3), (2002): 447-467.

Talley, W. K. "Wage Differentials of Intermodal Transportation Carriers and Ports: Deregulation Versus Regulation.” The Review of Network Economics 3 (2), (2004): 207-227.

Turner, H., R. Windle and M. Dresner. "North American Containerport Productivity: 1984-1997.” Transportation Research. Part E, Logistics \& Transportation Review 40E (4), (2004): 339-356.

United States Department of Transportation. National Strategy to Reduce Congestion on America's Transportation Network, 2006. 
Veras, J. H. and C. M. Walton. "State of the Practice of Information Technology at Container Ports." Transportation Research Record 1522, (1996): 87-93.

Vis, I. F. A. and R. de Koster. "Transshipment of Containers at a Container Terminal: An Overview." European Journal of Operational Research 147 (1), (2003): 1-16.

Wilbur Smith Associates. Latin America Trade and Transportation Study, 2001.

Michael Maloni is an assistant professor in the Coles College of Business at Kennesaw State University. Prior to returning to academia in 2004, Maloni managed $\$ 80$ million of marine transportation services for a third-party logistics company. He conducts research in third-party logistics and international transportation, and his work has been published in the Journal of Business Logistics, the Journal of Operations Management, the Transportation Journal, and the European Journal of Operational Research. Maloni holds a Ph.D. in Operations and Supply Chain Management from The Ohio State University.

Eric C. Jackson is an assistant professor in the Black School of Business at Pennsylvania State Erie. Jackson was the technical director for a multi-national specialty chemical firm for 10 years and was an engineering/business consultant for small firms in Toledo, Ohio, and Detroit. He also served as managerial assistant for the Decision Science Journal. He conducts research in supply chain management, project management, and complex dynamic systems. Jackson holds a Ph.D. from Michigan State University. 


\section{APPENDIX A: Survey Instrument}

Capacity Shortages: Please evaluate your agreement with the following statements:

\begin{tabular}{lcccccccc} 
Relative to container volumes: & $\begin{array}{c}\text { Strongly } \\
\text { Disagree }\end{array}$ & $\begin{array}{c}\text { Neither Agree } \\
\text { nor Disagree }\end{array}$ & $\begin{array}{c}\text { Strongly } \\
\text { Agree }\end{array}$ \\
\hline $\begin{array}{l}\text { Our capacity shortages will worsen } \\
\text { in the next } \mathbf{5} \text { years }\end{array}$ & 1 & 2 & 3 & 4 & 5 & 6 & 7 \\
$\begin{array}{l}\text { Our capacity shortages will worsen } \\
\text { in the next } \mathbf{1 0} \text { years }\end{array}$ & 1 & 2 & 3 & 4 & 5 & 6 & 7 \\
\hline
\end{tabular}

Capacity Factors: Please assess the significance of the following factors in affecting your port's capacity in the next 5-10 years:

\begin{tabular}{|c|c|c|c|c|c|c|c|}
\hline Port Infrastructure & \multicolumn{2}{|c|}{$\begin{array}{c}\text { No } \\
\text { Significance }\end{array}$} & \multicolumn{3}{|c|}{$\begin{array}{c}\text { Moderate } \\
\text { Significance }\end{array}$} & \multicolumn{2}{|c|}{$\begin{array}{c}\text { High } \\
\text { Significance }\end{array}$} \\
\hline Available land for port expansion & 1 & 2 & 3 & 4 & 5 & 6 & 7 \\
\hline Berth space & 1 & 2 & 3 & 4 & 5 & 6 & 7 \\
\hline Container yard/terminal space & 1 & 2 & 3 & 4 & 5 & 6 & 7 \\
\hline Terminal operator capacity & 1 & 2 & 3 & 4 & 5 & 6 & 7 \\
\hline Gate capacity and congestion & 1 & 2 & 3 & 4 & 5 & 6 & 7 \\
\hline Port equipment (e.g. cranes, etc.) & 1 & 2 & 3 & 4 & 5 & 6 & 7 \\
\hline
\end{tabular}

\section{Labor}

No

Significance

High Significance

\begin{tabular}{|l|ccccccc|}
\multicolumn{1}{c}{ Significance } & \multicolumn{3}{c}{ Significance } & \multicolumn{3}{c|}{ Significance } \\
\hline Longshoremen labor capacity & 1 & 2 & 3 & 4 & 5 & 6 & 7 \\
Longshoremen labor costs & 1 & 2 & 3 & 4 & 5 & 6 & 7 \\
Longshoremen labor efficiency & 1 & 2 & 3 & 4 & 5 & 6 & 7 \\
Other port labor capacity & 1 & 2 & 3 & 4 & 5 & 6 & 7 \\
Other port labor costs & 1 & 2 & 3 & 4 & 5 & 6 & 7 \\
Other port labor efficiency & 1 & 2 & 3 & 4 & 5 & 6 & 7 \\
\hline
\end{tabular}

\begin{tabular}{|c|c|c|c|c|c|c|c|}
\hline \multirow{2}{*}{$\begin{array}{l}\text { Waterways } \\
\text { Channel depth }\end{array}$} & \multicolumn{2}{|c|}{$\begin{array}{c}\text { No } \\
\text { Significance } \\
\end{array}$} & \multicolumn{3}{|c|}{$\begin{array}{c}\text { Moderate } \\
\text { Significance }\end{array}$} & \multicolumn{2}{|c|}{$\begin{array}{c}\text { High } \\
\text { Significance } \\
\end{array}$} \\
\hline & 1 & 2 & 3 & 4 & 5 & 6 & 7 \\
\hline Channel width & 1 & 2 & 3 & 4 & 5 & 6 & 7 \\
\hline Channel congestion & 1 & 2 & 3 & 4 & 5 & 6 & 7 \\
\hline Bridge clearance & 1 & 2 & 3 & 4 & 5 & 6 & 7 \\
\hline Barge, short sea feeders & 1 & 2 & 3 & 4 & 5 & 6 & 7 \\
\hline
\end{tabular}




\begin{tabular}{|l|lllllll|}
\multicolumn{1}{c}{} & \multicolumn{1}{c}{ No } & \multicolumn{1}{c}{$\begin{array}{c}\text { Moderate } \\
\text { Significance }\end{array}$} & \multicolumn{2}{c|}{$\begin{array}{c}\text { High } \\
\text { Significance }\end{array}$} \\
\hline Rail - on-dock capacity & 1 & 2 & 3 & 4 & 5 & 6 & 7 \\
Rail - local capacity & 1 & 2 & 3 & 4 & 5 & 6 & 7 \\
Rail - national capacity & 1 & 2 & 3 & 4 & 5 & 6 & 7 \\
Trucking - local drayage capacity & 1 & 2 & 3 & 4 & 5 & 6 & 7 \\
Trucking - long-haul capacity & 1 & 2 & 3 & 4 & 5 & 6 & 7 \\
Local road and highway capacity & 1 & 2 & 3 & 4 & 5 & 6 & 7 \\
National highway capacity & 1 & 2 & 3 & 4 & 5 & 6 & 7 \\
\hline
\end{tabular}

\section{Technology Improvements}

Moderate

High

\begin{tabular}{|l|cccccccc|}
\multicolumn{1}{c}{ Significance } & \multicolumn{3}{c}{ Significance } & \multicolumn{3}{c|}{ Significance } \\
\hline Data exchange between port, partners & 1 & 2 & 3 & 4 & 5 & 6 & 7 \\
Scheduling (loading, unloading, etc.) & 1 & 2 & 3 & 4 & 5 & 6 & 7 \\
Container tracking & 1 & 2 & 3 & 4 & 5 & 6 & 7 \\
Gate systems & 1 & 2 & 3 & 4 & 5 & 6 & 7 \\
\hline
\end{tabular}

\begin{tabular}{|l|ccccccc|}
\multicolumn{1}{c}{ Government and Community } & \multicolumn{1}{c}{$\begin{array}{c}\text { No } \\
\text { Significance }\end{array}$} & \multicolumn{2}{c}{$\begin{array}{c}\text { Moderate } \\
\text { Significance }\end{array}$} & \multicolumn{2}{c|}{$\begin{array}{c}\text { High } \\
\text { Significance }\end{array}$} \\
\hline Security compliance & 1 & 2 & 3 & 4 & 5 & 6 & 7 \\
Federal issues & 1 & 2 & 3 & 4 & 5 & 6 & 7 \\
State issues & 1 & 2 & 3 & 4 & 5 & 6 & 7 \\
Local community issues & 1 & 2 & 3 & 4 & 5 & 6 & 7 \\
Environmental issues & 1 & 2 & 3 & 4 & 5 & 6 & 7 \\
\hline
\end{tabular}

Expected Stakeholder Participation: Please assess current levels of expected participation (i.e. articipation that is necessary) of these stakeholders in helping to address your capacity issues:

\begin{tabular}{|l|lllccccc|}
\hline \multirow{2}{*}{ Stakeholder } & \multicolumn{7}{c}{ Expected Participation } \\
& None & & & Medium & & High \\
\hline Your port leadership & 1 & 2 & 3 & 4 & 5 & 6 & 7 \\
Terminal operator(s) & 1 & 2 & 3 & 4 & 5 & 6 & 7 \\
Longshoremen labor/union(s) & 1 & 2 & 3 & 4 & 5 & 6 & 7 \\
Steamship lines & 1 & 2 & 3 & 4 & 5 & 6 & 7 \\
Shippers, cargo owners & 1 & 2 & 3 & 4 & 5 & 6 & 7 \\
Forwarders, customs brokers & 1 & 2 & 3 & 4 & 5 & 6 & 7 \\
Railroads & 1 & 2 & 3 & 4 & 5 & 6 & 7 \\
Local drayage companies & 1 & 2 & 3 & 4 & 5 & 6 & 7 \\
Long-haul trucking companies & 1 & 2 & 3 & 4 & 5 & 6 & 7 \\
Federal agencies, government & 1 & 2 & 3 & 4 & 5 & 6 & 7 \\
State agencies, government & 1 & 2 & 3 & 4 & 5 & 6 & 7 \\
Local agencies, government & 1 & 2 & 3 & 4 & 5 & 6 & 7 \\
Local community & 1 & 2 & 3 & 4 & 5 & 6 & 7 \\
\hline
\end{tabular}


Stakeholder Contributions

Actual stakeholder participation: please assess current levels of actual participation (i.E.

Participation currently offered) by these stakeholders in helping to address your capacity issues:

\begin{tabular}{|c|c|c|c|c|c|c|c|}
\hline \multirow{2}{*}{$\begin{array}{l}\text { Stakeholder } \\
\text { Your port leadership }\end{array}$} & \multicolumn{5}{|c|}{$\begin{array}{c}\text { Actual Participation } \\
\text { Medium }\end{array}$} & \multicolumn{2}{|c|}{ High } \\
\hline & 1 & 2 & 3 & 4 & 5 & 6 & 7 \\
\hline Terminal operator(s) & 1 & 2 & 3 & 4 & 5 & 6 & 7 \\
\hline Longshoremen labor/union(s) & 1 & 2 & 3 & 4 & 5 & 6 & 7 \\
\hline Steamship lines & 1 & 2 & 3 & 4 & 5 & 6 & 7 \\
\hline Shippers, cargo owners & 1 & 2 & 3 & 4 & 5 & 6 & 7 \\
\hline Forwarders, customs brokers & 1 & 2 & 3 & 4 & 5 & 6 & 7 \\
\hline Railroads & 1 & 2 & 3 & 4 & 5 & 6 & 7 \\
\hline Local drayage companies & 1 & 2 & 3 & 4 & 5 & 6 & 7 \\
\hline Long-haul trucking companies & 1 & 2 & 3 & 4 & 5 & 6 & 7 \\
\hline Federal agencies, government & 1 & 2 & 3 & 4 & 5 & 6 & 7 \\
\hline State agencies, government & 1 & 2 & 3 & 4 & 5 & 6 & 7 \\
\hline Local agencies, government & 1 & 2 & 3 & 4 & 5 & 6 & 7 \\
\hline Local community & 1 & 2 & 3 & 4 & 5 & 6 & 7 \\
\hline
\end{tabular}

